Kok M., H. Massinen, I. Moshnikov, E. Penttilä, S. Tavi \& L. Tuomainen (toim.) 2019. Pidetään kielet elävinä - Keeping languages alive - Piemmö kielet elävinny. AFinLAn vuosikirja 2019. Suomen soveltavan kielitieteen yhdistyksen julkaisuja n:o 77. Jyväskylä. s. 101-119.

Henri Satokangas

Helsingin yliopisto

\title{
Termien selittäminen multimodaalisena toimintana yleistajuisissa tietokirjoissa
}

The article studies how visual images and their use in explaining field-specific terms can be analyzed with the concept of discourse patterns. When expounding and demonstrating the meaning of specialized terminology in popular non-fiction, different kinds of pictures are utilized to scaffold the reader-in-the-text's understanding of the meanings of such field-specific terms. In the article, explanation sequences are analyzed as multimodal discourse patterns, where verbal text and images together produce knowledge-constructing interaction. Diverse resources of presenting information (e.g. genre features of written text, coding orientations of visual image) construct the interactive functions of a multimodal text. For example, a technologically oriented image can realize both functions in the introduction-description pattern whereas an image depicting a particular situation can function as an exemplification in the introduction-exemplification pattern. The analysis of discourse patterns aims to examine the ways of representing conceptual knowledge in research popularizations.

Keywords: multimodality, text analysis, nonfiction

Asiasanat: multimodaalisuus, tekstianalyysi, tietokirjallisuus 


\section{Johdanto}

Tarkastelen tässä artikkelissa termien selittämistä multimodaalisena toimintana yleistajuisissa tietokirjoissa. Suomenkielisten termien tunnetuksi ja ymmärrettäväksi tekeminen yleistajuisessa tiedeviestinnässä mahdollistaa uusia käyttöaloja suomen kielelle. Erikoisalan termejä tehdään ymmärrettäviksi ja niiden merkitystä avataan käyttämällä kielellisten selitysten lisäksi kuvia ja muita visuaalisia havainnollistamiskeinoja. Selittäminen on vuorovaikutustoimintana tyypillisesti multimodaalista (esim. Järvinen 2001: 191-193): jotta asia saadaan mahdollisimman ymmärrettäväksi vastaanottajalle, on tarkoituksenmukaista muotoilla tietoa monella eri tavalla ( $\mathrm{ks}$. Butcher 2014). Tietokirjan kontekstissa kieli saa parikseen kuvat ja muun visuaalisen ilmaisun, kuten graafit ja typografian. Myös asettelu ja kuvatekstit rakentavat kirjan sivuista tietokirjalle ominaista semioottista tilaa.

Käsittelen tässä termien selitysjaksoja eli niitä funktionaalisesti määrittyviä tekstijaksoja, joissa lukijalle eksplisiittisesti avataan jonkin erikoisalan termin merkitystä. Selitysjaksoja tarkastelemalla esittelen, kuinka kirjoitetun vuorovaikutuksen näkökulmaa (ks. Rahtu, Shore \& Virtanen 2018 toim.; Virtanen \& Kääntä 2018) ja toimintokuvion käsitettä (ks. esim. Hoey 2001: 122; Virtanen 2015: 39-41) voidaan soveltaa multimodaalisen tekstin analyysiin. Toimintokuvioilla tarkoitan lukijan johdatteluun käytettyjä retorisia rakenteita (ks. luku 3.2). Tutkin, millaisissa tehtävissä kuvallisia selityskeinoja tietokirjoissa käytetään eli kuinka ne toimivat osana tietokirjatekstiin kirjoitettua vuorovaikutusta. Lukijalle muotoiltava käsitteellinen tieto ilmaistaan siis eri modaliteettien yhteispelinä. Tekstien multimodaalisessa analyysissa kuvia tarkastellaan semioottisina järjestelminä, jotka itsessään esittävät tietoa ja rakentavat merkityksiä (Lynch 1990: 153; Lemke 1998). Kirjoitettua ja kuvallista ilmaisua yhdisteleviä kokonaisuuksia käsitellään laajan tekstikäsityksen mukaisesti multimodaalisina teksteinä, joissa kirjoitus ja kuva yhdessä rakentavat merkitystä.

Kun kuvaa ja sanaa yhdistäviä tekstikokonaisuuksia on tutkittu, lähtökohdaksi on usein otettu systeemis-funktionaaliseen (SF) kieliteoriaan (esim. Halliday \& Matthiessen 2014) ja kielen metafunktioihin perustuva sosiosemioottinen analyysi (Kress \& van Leeuwen 1996). SF-perustaisen analyysin ongelmaksi on toisinaan esitetty, että se tarkastelee modaliteetteja yksityiskohtaisesti mutta toisistaan irrallaan, jolloin niiden yhdessä muodostamat merkitykset jäävät helposti vaillinaisesti käsitteellistetyiksi (esim. Forceville 2007: 1235-1236; Ketola 2018: 35-36; vrt. myös Machin \& Jaworski 2006: 361-362). Pyrin osoittamaan, että tämä sudenkuoppa voidaan välttää analysoimalla multimodaalista kirjoitettua vuorovaikutusta toimintokuvioiden avulla, tarkastelemalla multimodaalisen kokonaisuuden rakentamaa toimintaa. Kuvaa ja sanaa yhdistävien tiedon rakentamisen strategioiden tuntemuksella on käytännön sovellusmahdollisuuksia niin perus- ja keskiasteen tekstitaitojen opetuksessa kuin tutkimusta popularisoivien tutkijoiden ja oppikirjailijoiden koulutuksessa. 
Käyn aluksi läpi tutkimukseni lähtökohtia. Analyysiosiossa esittelen kahden esimerkin avulla, kuinka multimodaaliseen tekstiin kirjoitettua vuorovaikutusta voidaan jäsentää toimintokuvioiksi; lähtökohtana on se toiminto, jota kuva toteuttaa osana selitysjaksoa. Lopuksi vedän havaintoja yhteen.

\section{Aineisto}

Tämän artikkelin tutkimusaineistona on kaksi esimerkkitapausta, joilla havainnollistan multimodaalisia toimintokuvioita. Tarkastelemani esimerkit on poimittu varsin erilaisia tieteenaloja (merentutkimus ja uskontotiede) edustavista tietokirjoista. Esimerkkejä erottaa myös se, että kuvan ja sanan suhde jäsentyy esimerkeissä eri tavoin.

Ensimmäinen esimerkkini on peräisin teoksesta Meret - maapallon siniset kasvot (Ursa 2014). Kyseessä on merentutkimusta varsin kattavasti yleistajuistava tietokirja, ja sen ovat kirjoittaneet oseanografi Kai Myrberg ja geofyysikko Matti Leppäranta. Esipuheessa tekijät mainitsevat teoksen olevan "ensimmäinen maapallon valtameristä tehty yleistajuinen suomenkielinen tietokirja" (Myrberg \& Leppäranta 2014: 7). Sen eksplisiittinen tavoite on saattaa suomenkielistä tutkimustietoa meristä suuren yleisön saataville. Toinen esimerkkini on uskontotieteilijä Risto Pulkkisen kirjasta Suomalainen kansanusko - samaaneista saunatonttuihin (Gaudeamus 2014), joka esittelee kansanuskomusten näkemyksiä maailmankaikkeudesta sekä erilaisia uskomusolentoja. Monet käytetyistä nimityksistä ovat tuttuja myös yleiskielestä. $\mathrm{Ni}$ mitykset asettuvat teoksessa kuitenkin erityisalan taksonomiaan ja niitä käytetään termeinä. Kummassakin teoksessa kuvitusta on runsaasti, ja kuvat liittyvät usein juuri esiteltäviin ja selitettäviin termeihin.

Esimerkkien käsittely perustuu Tiedonkerronta-hankkeessa (ks. Hiidenmaa ym. 2018) kerätyn tietokirja-aineiston analyysiin. Aineisto koostuu 2010-luvulla julkaistuista yleistajuisista (Julkaisufoorumi-luokitus E2) suomenkielisistä tietokirjoista, jotka ovat akateemisten tutkijoiden omasta alastaan kirjoittamia. Tunnistetut toimintokuviot pohjautuvat tästä aineistosta tehtyyn laajempaan termien selittämisen analyysiin (ks. Satokangas tulossa).

\section{Tausta}

Käsittelen seuraavissa alaluvuissa ensin multimodaalisuutta kielentutkimuksessa yleisesti ja sitten tarkemmin termien selittämistä multimodaalisena vuorovaikutuksena tietokirjoissa. Tästä eteenpäin viittaan käytännön syistä tekstillä kirjoitettuun kieleen ja kuvalla sellaisiin visuaalisiin elementteihin kuin valokuviin, piirroksiin, kaavakuviin ja graafeihin (vrt. Heikkilä 2006: 17; Koivisto 2011:21). 


\subsection{Tekstin ja kuvan yhteispeli}

Kuvan ja sanan suhdetta on tutkittu lingvistiikassa paljon 1990-luvulta lähtien. Usein multimodaalisessa analyysissa kuitenkin yhdistetään eri tieteenalojen lähtökohtia, ja alue onkin perinteisesti ollut monitieteinen. Esimerkiksi Mikkonen (2005) tarkastelee kuvan ja sanan suhdetta kirjallisuuden- ja taiteentutkimuksen näkökulmasta. Kuvan ja sanan suhde on keskeinen tutkimuskohde kuvakirjojen tutkimuksessa (esim. Nikolajeva \& Scott 2006), myös kuvakirjojen kääntämisen näkökulmasta (esim. Oittinen ym. 2017). O'Toole (1994) puolestaan lähestyy eri taiteenlajeja systeemis-funktionaalisen kieliopin näkökulmasta ja soveltaa SF-analyysia eri modaliteetteihin, aina runoudesta maalauksiin ja arkkitehtuuriin. Kressin ja van Leeuwenin (1996) sosiosemioottisessa analyysimallissa kuvia tarkastellaan niin ikään SF-kieliopin ja kielen metafunktioiden pohjalta, esimerkiksi erittelemällä niiden representoimia prosessityyppejä ja niissä esiintyviä elementtejä. Malli tarkastelee myös muun muassa kuvien modaalisuutta koodausorientaation käsitteen avulla (suomenkielinen esittely ks. Heikkilä 2006: 25-29).

Kuvallisella ilmaisulla on erityinen rooli tieteellisen tiedon yleistajuisessa esittämisessä (esim. Hyland 2010: 119), ja eri tieteenaloille on vakiintunut omat keinonsa esittää tietoa visuaalisesti (esim. Lemke 1998; Coopmans ym. 2014). Kuvat ovat tyypillisiä myös tiedettä yleistajuistavissa blogeissa, joissa kuva saa usein selittävän tekstin, jotta se on ymmärrettävä (Luzón 2013: 446). Kuvitukseen panostaminen on 2000-luvulla muodostunut tärkeäksi osaksi myös yleistajuista tietokirjallisuutta, siinä missä se lasten tietokirjoissa on ollut olennainen osa jo kauan (Löytönen 2017). Käsitteenmäärittelyn ja kuvituksen suhde on tiivis myös esimerkiksi sanakirjoissa (esim. Hovmark 2010). Lisäksi internet-meemien tutkimuksessa lähtökohtana on usein kuvan ja tekstin yhteispelin tulkinta (esim. Dancygier \& Vandelanotte 2017).

Multimodaalisen selittämisen rakentumiseen voidaan päästä käsiksi tarkastelemalla, miten tekstin ja kuvan representoimat prosessit vastaavat toisiaan, millainen suhde tekstin ja kuvan esittämällä informaatiolla on toisiinsa ja kuinka teksti ja kuva viittaavat toisiinsa. Oma keskeinen roolinsa on ns. parateksteillä (ks. Hiidenmaa 2018), etenkin kuvateksteillä, ja niiden suhteella yhtäältä leipätekstiin ja toisaalta kuvaan. Olennaista on tunnistaa multimodaalisen tekstikokonaisuuden sisäisiä merkityssuhteita (ks. Unsworth \& Cléirigh 2009; Martinec \& Salway 2005; Bateman 2008), joille selittämisen toimintokuviot rakentuvat. Usein lähtökohtana merkityssuhteiden analyysissa on yhtäältä tekstin ja toisaalta kuvan esittämä informaatio. Bateman (2008) ja Hiippala (2013) hyödyntävät multimodaalisen kokonaisuuden sisäisten merkityssuhteiden analyysissaan retorisen rakenteen teoriaa (Rhetorical Structure Theory, ks. Mann \& Thompson 1988; Komppa 2012). Heikkilän (2006) ja Koiviston (2011) sanomalehtiaineistoa käsittelevissä tutkimuksissa kuvien ja kuvatekstien informaatiota tarkastellaan ja luokitellaan suhteessa leipätekstiin. Kattavan esityksen erilaisista tavoista nimetä kuvan ja tekstin välisiä suhteita tarjoavat Marsh ja White 
(2003) meta-analyyttisessa artikkelissaan, jossa he jakavat suhteet kolmia. Kuva voi ensinnäkin olla vain löyhässä suhteessa tekstiin ja toimia esimerkiksi koristeena tai tunteiden herättäjänä. Se voi myös ilmaista kiinteää suhdetta tekstiin vaikkapa havainnollistamalla ja selittämällä tekstiä. Kolmanneksi kuva voi laajentaa näkökulmaa tekstin ulkopuolelle esimerkiksi tulkitsemalla tai kehittämällä pidemmälle tekstin teemoja.

\subsection{Selittäminen kielellisenä ja multimodaalisena toimintana}

Tieteen yleistajuistamisen kielellisiä ominaisuuksia tarkasteltaessa termien selittäminen on yleensä huomioitu yhtenä keskeisenä yleistajuistamisen kielellisenä piirteenä (esim. Mäntynen 2003: 124-126; Calsamiglia \& van Dijk 2004; Hyland 2010: 121; Luzón 2013: 443). Termien käsittelyyn kiinnitetään huomiota myös tieteen yleistajuistamisen oppaissa (esim. Rahtu 2013: 109-113; Raevaara 2016: 87). Termin näen tässä erikoiskieleen kuuluvan käsitteen nimityksenä, niin kuin se terminologian teoriassa ymmärretään (esim. TSK 1988: 25; Pasanen 2015: 179). Termistö onkin yleistajuisen ja tieteellisen diskurssin näkyvä leikkauspiste, jossa eri diskurssien välinen jännite on purettava tavalla tai toisella: joko välttämällä erikoistermien käyttöä tai selittämällä ne auki. Termien selittämisen voikin nähdä diskurssien yhteensovittamisena (Karvonen 1995: 123, 149) tai kääntämisenä diskurssista toiseen (Wignell, Martin \& Eggins 1993: 149-150). Monet kuitenkin puhuvat mieluummin rekontekstualisoimisesta (Calsamiglia \& van Dijk 2004: 371; Hyland 2010: 117; Luzón 2013: 429). Yksi rekontekstualisoimisen keino on muotoilla tieto visuaalisesti suurelle yleisölle sopivaksi. Hylandin (2010: 119) mukaan tieteellisessä tekstissä kuvat esittävät todisteita päätelmille, kun taas yleistajuisessa esityksessä niiden tehtävä on selittää ja havainnollistaa kirjoitettua tekstiä sekä houkutella lukijoita.

Tietokirjateksti multimodaalisena tekstikokonaisuutena voidaan nähdä dialogisesti tekstiin kirjoittuvien kirjoittaja- ja lukijaposition vuorovaikutuksena, jossa kirjoittaja muotoilee informaatiota oletetun kohdelukijansa odotusten, kysymysten ja tarpeiden mukaan ja johdattelee tätä tekstissä eteenpäin. ${ }^{1}$ Kielentutkimuksessa selittämistä on tarkasteltu erityisesti kahdesta näkökulmasta, jotka poikkeavat toisistaan selittämisen kohteen ja sovelletuimpien menetelmien suhteen. Ensinnäkin selittäminen on käsitetty syy-seuraussuhteiden ilmi tuomisena ja prosessien selostamisena, jota on tarkasteltu genreanalyysin kautta (esim. Martin \& Rose 2008: 150-165; Rose \& Martin 2012: 130; suomeksi Shore 2014: 46). Toiseksi selittämistä

$1 \quad$ Dialogismista ks. esim. Thompson 2012: 78-79; Makkonen-Craig 2014; Virtanen 2015: 25-30. Tekstiin kirjoittuvista kirjoittajasta ja lukijasta esim. Thompson \& Thetela 1995; Karvonen 1995: 17-19; Hoey 2001: 13-15; Virtanen 2015: 29; Rahtu ym. 2018. Kirjoittaja on siis tekstin positio, joka voi syntyä kirjailijan, kuvittajan, kustannustoimittajan, kääntäjän ja muiden mahdollisten tekijöiden yhteistyön tuloksena. 
on tarkasteltu sanojen merkityssisällön avaamisena, joka on ollut tyypillinen tutkimuskohde toisen tai vieraan kielen sanaston opettamisen tutkimuksessa; tässä menetelmänä on usein keskustelunanalyysi (esim. Järvinen 2001; Dalton-Puffer 2007; Morton 2015; Merke 2016). Omassa analyysissani hyödynnän kumpaakin lähestymistapaa: termien selittämisessä kyse on yhtäältä yksittäisen kielenyksikön merkityssisällön uudelleenmuotoilusta ja vuorovaikutuksesta mutta myös kausaalisuhteiden esilletuomisesta, erityisesti jos kyse on erilaisia prosesseja nimeävistä termeistä.

Lähestyn vuorovaikutuksen etenemistä multimodaalisen toimintokuvion käsitteen kautta. Toimintokuviolla tarkoitan kulttuurisesti vakiintuneita ja retorisia kielellisten toimintojen yhteenliittymiä, jotka ohjaavat sekä puheen ja tekstin tuottamista että niiden tulkintaa (ks. esim. Hoey 1983: 31, 2001: 122; Thompson 2001; Virtanen 2015: 39-41); tällaisia yhteenliittymiä ovat esimerkiksi ongelma-ratkaisu ja mielipide-perustelu. Eri tekstilajeista voidaan usein löytää juuri niille luonteenomaiset toimintokuviot, jotka ovat tarkoituksenmukaisia lajin tavoitteiden kannalta: esimerkiksi tieteellisten termien selittämisen tavallisia toimintokuvioita ovat MÄ̈̈RITTELY-KUVAUS ja KUVAUS-NIMEÄMINEN (Satokangas tekeillä). ${ }^{2}$

Toimintokuvioita on tunnistettu ja analysoitu lähinnä kirjoitetusta tekstistä, joka on useimmiten lähtökohtaisesti lineaarista eli rakentuu toisiaan yhdessä linjassa seuraavista yksiköistä. Tässä artikkelissa sovellan toimintokuvion ajatusta multimodaalisiin tekstikokonaisuuksiin, joissa lukeminen on luonteeltaan multilineaarista ja multisekventiaalista. Tekstin ja kuvan kokonaisuuksiin on kirjoittunut erilaisia lukureittejä, joita seuraamalla vuorovaikutus jäsentyy eri tavalla. Käsitteellä lukupolku on multimodaalisen analyysin perinteessä puolestaan kuvattu lukemisen etenemistä semioottisessa tilassa tekstielementistä toiseen (Kress \& van Leeuwen 1996: 218222; Nord 2008: 166; Koponen ym. 2017: 66-67). On huomattava, että yksinomaan kirjoitetuissa teksteissä esiintyy niissäkin multilineaarisuutta, vaikkapa alaviitteissä ja hyperlinkeissä sekä sellaisissa asetteluun liittyvissä ratkaisuissa kuin numerointi, listat ja luettelomerkit. Kuvaan viittaaminen luo vaihtoehtoisia lukijarooleja samaan tapaan kuin alaviite (Lemke 1998) tai hyperlinkki (Luzón 2009; Vitikka 2018): viitettä tai linkkiä voi seurata tai olla seuraamatta. Multimodaalisen toimintokuvion ajatukselle on keskeistä, että niin kuva, määritelmä, kertomus kuin muukin tekstijakso voi suorittaa samaa retorista toimintoa: ratkaisevaa on tekstin osien suhde toisiinsa.

Tekstiin kirjoitettujen retoristen kuvioiden tarkastelu on syytä erottaa ensinnäkin silmänliikkeiden ja toiseksi lukupolun tutkimisesta. Dialogistisesta näkökulmasta toimintojen ja niiden muodostamien kuvioiden analyysi keskittyy siihen, millaiseksi kirjoittajan ja lukijan vuorovaikutus jäsentyy. Tämä saadaan selville malliluennalla (ks. Nord 2008: 56-57), joka on tekstin kielellisiin ja kuvien semioottisiin ominaisuuksiin perustuva esitys multimodaaliseen tekstikokonaisuuteen kirjoittu-

2 Erotan toimintojen nimet muusta tekstistä tekstintutkimuksen käytännön mukaisesti pienillä kapiteeleilla (ks. esim. Virtanen \& Kääntä 2018: 142). 
neesta toiminnasta. Missä kohtaa tekstiä kuvaan viitataan, kuinka kirjoittaja johdattaa kuvaan ja miten ohjaa lukemaan sitä juuri tietyssä vaiheessa ja tiettyä esitettyä tietoa vasten? Tämä saattaa tapahtua eri järjestyksessä kuin missä todellisen lukijan katse multimodaalisen tekstin ääressä etenee. Taittoon ja asetteluun liittyvät ratkaisut vaikuttavat toki todelliseen luentaan, mutta käsittelen niitä käytännön syistä tässä vain sivuten. Olennainen onkin kuvan ns. tarttumakohta eli se kohta tekstissä, johon kuva eksplisiittisesti kiinnittyy esimerkiksi tekstissä olevan suoran viittauksen kautta (ks. Heikkilä 2006: 237-239). Metateksti ja viittaukset eri tekstielementtien välillä rakentavat vuorovaikutuksen etenemistä multimodaalisissa tietokirjateksteissä. Kuva voi olla yksi toiminto kuviossa (vrt. Nord 2008: 115-116). Se täyttää tehtävänsä osana tekstiin kirjoittuvaa toimintaa. Kuvat ja infografiikka siis asettuvat osaksi selityskuvioita ja rakentavat niitä osaltaan.

\section{$4 \quad$ Kumpuamisen ja metsänhaltijan multimodaaliset terminselitysjaksot}

Esittelen tässä luvussa kolme erilaista tapaa, joilla kuva toimii osana termiä selittävää toimintokuviota: esittely, kuvaus ja esimerkki. Tarkastelen, miten kirjoittaja rakentaa kuvat osaksi tietokirjatekstin vuorovaikutuksen etenemistä. Analysoin ensinnäkin kuvia autonomisina tiedon esittämisen resursseina ja toiseksi niiden punoutumista osaksi kirjoitettua vuorovaikutusta. Käyttämäni kaksi aineistoesimerkkiä olen valinnut havainnollistamaan erilaisia tietokirjatekstille tyypillisiä multimodaalisia toimintokuvioita. Samalla ne edustavat erilaisia tiedon kuvallisen esittämisen resursseja.

Tarkastellessani kuvaa tiedon esittämisen resurssina keskeinen näkökulma on Kressin ja van Leeuwenin (1996) ajatus kuvan modaalisuudesta eli siitä, miten ja missä mielessä todenmukaisena kuva tulkitaan kontekstissaan. He nimittävät modaalisuuden erilaisia kontekstisidonnaisia tulkintaperiaatteita koodausorientaatioiksi (coding orientation), joita on kaikkiaan neljä. Ensinnäkin koodausorientaatioltaan naturalistista kuvaa käytetään esitettäessä kohde mahdollisimman samankaltaisena kuin se todellisuudessa nähdään. Tyyppiesimerkkinä naturalistisesti orientoituneesta kuvasta voidaan pitää värivalokuvaa tai eläinlajin tunnistuskuvaa. Toiseksi, tieteellis-teknologisessa koodausorientaatiossa korostuu juuri tiettyjen, kontekstissaan keskeisten piirteiden tehokas esittäminen. Esimerkkejä tästä ovat erilaiset kaavakuvat. Kolmanneksi, aistillisessa koodausorientaatiossa painottuu aistillinen elämys, jopa nautinto - esimerkkinä vaikkapa impressionistinen maalaus. Neljänneksi, abstraktissa koodausorientaatiossa korostuvat kuvattavan kohteen abstrahoidut olemuspiirteet. Esimerkki tästä on käsitediagrammi. (Mts. 168-171.) 


\subsection{Kuva esitTELYNÄ ja KUVAUKSENA}

Prosessien kuvaamisessa visuaalinen havainnollistus on usein tarpeen. Esimerkissä 1 kirjoittaja esittelee ja avaa lukijalle oseanografisen termin kumpuaminen. Kyse on erityisestä veden liikkeestä, jonka syntyyn vaikuttavat tuuliolosuhteet. Jotta lukija voi ymmärtää ilmiön, tulee hänen hahmottaa myös sen taustalla vaikuttava tapahtumasarja eli syy-seuraussuhteet. Kirjoittaja selittää termin toimintokuviolla ESITTELYKUVAUS, jossa termi ja sen nimeämä ilmiö tehdään ensin tutuksi käsitteellisellä tasolla ja siirrytään sitten sen tarkempaan kuvailemiseen.

\section{(1) Kumpuaminen ja painuminen}

Tuulen ajovirta aiheuttaa tietyissä tilanteissa myös huomattavaa pystysuuntaista virtausta. Nousevaa virtausta pinnalle kutsutaan kumpuamiseksi ja vastaavasti laskevaa virtausta painumiseksi. Kumpuaminen on erityisen tärkeä mekanismi, sillä se voi tuoda syvemmältä kylmempää, ravinteikasta vettä pintaan (kuva 3-10). $--$

Kumpuamista voi esiintyä sekä avomerellä että rannikolla. Avomerellä se voi olla varsin laaja-alaista ja pysyvää. - - [Avomeren kumpuamisen kuvausta.]

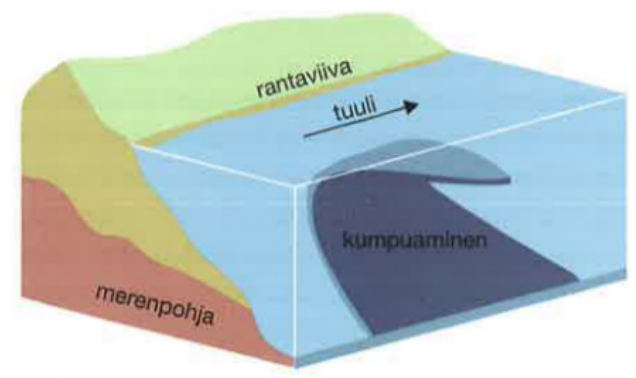

Kuva 3-10. Rannikon läheinen kumpuaminen. Jos pohjoisella pallonpuoliskolla tuuli puhaltaa rannikon suuntaisesti siten, että rannikko on tuulen suuntaan katsottuna vasemmalla, vesi kulkeutuu Ekman-teorian mukaan avomerelle päin. Rannikolta poistuva vesi korvautuu syvemmän veden kumpuamisella pinnalle. Voimakkain kumpuaminen tapahtuu kapealla vyöhykkeellä rannikon tuntumassa, mutta vaikutukset näkyvät laajemmalla alueella.

\section{[Sivunvaihto]}

Toinen tyypillinen ja tärkeä kumpuamisen alue on rannikkovyöhyke. Jos pohjoisella pallonpuoliskolla tuuli puhaltaa rannikon suuntaisesti siten, että rannikko on tuulen suuntaan katsottuna vasemmalla, vesi kulkeutuu Ekman-teorian mukaan tuulen suunnasta oikealle eli avomerelle päin. Rannikolta poistuva vesi korvautuu syvemmän veden kumpuamisella pinnalle. Päinvastaisessa tapauksessa ulkomeren vesi ajautuu rantaan päin ja tapahtuu pintaveden painumista syvempään. Myös rannikolta avomerelle suuntautuvat tuulet aiheuttavat tilapäistä kumpuamista virtauskentän kehittymisen aikana.

(Myrberg \& Leppäranta 2014: 43-44.) 
Jo luvun otsikko Kumpuaminen ja painuminen merkitsee kaksi ilmiötä keskeisiksi ja ohjaa lukijaa keskittymään näihin kahteen termiin. Leipätekstissä kirjoittaja määrittelee kumpuamisen passiivimuotoisen kommunikaatioverbin kutsutaan avulla (ks. Karvonen 1995: 122): Nousevaa virtausta pinnalle kutsutaan kumpuamiseksi ja vastaavasti laskevaa virtausta painumiseksi. Samassa virkkeessä termi saa siis sen merkityssisältöä ilmaisevan parafraasin (pinnalle) nouseva virtaus ja vieruskäsitteen painuminen (ks. TSK 1988: 29), jonka myötä termi asettuu osaksi käsitejärjestelmää (Lemke 1990: 17; Karvonen 1995: 122). Passiivimuotoinen verbi konstruoi tekstiin kollektiivin, jonka keskuudessa nimitystä käytetään (ks. Pälli 2003: 112). Tässä kollektiivin identiteetti jää implisiittiseksi, mutta Meret-teos kontekstina ohjaa tulkitsemaan sen tiedeyhteisön ja tarkemmin merentutkimuksen yhteisön ääneksi (vrt. Virtanen 2015: 46-48). Määrittelyn jälkeen kirjoittaja esittää kontekstitietoa ilmiöstä evaluoimalla sen merkittävyyttä (erityisen tärkeä mekanismi; relevanssin evaluoinnista ks. Thompson \& Hunston 2000: 24) ja selostamalla sen tyypillisiä esiintymispaikkoja. Samalla kumpuaminen saa yläkäsitteen mekanismi, joka luonnehtii, mihin luokkaan kuuluvasta ilmiöstä on kyse. Merkittävyyttä arvioivan virkkeen lopussa on viittaus kuvaan 3-10 eli kuvan ensimmäinen tarttumakohta (ks. Heikkilä 2006: 237).

Tietokuvituksen lajina kyseessä on läpileikkauskuva (Koponen ym. 2017: 140): lukijan näkyviin on asetettu ilmiön ymmärtämisen kannalta olennaiset asiat eli ranta, vesi ja vedessä tapahtuva vesimassan liike sekä tuuli. Kuva näyttää siis tekstissä esiteltyjä termin kumpuaminen käsitepiirteitä: ympäristönä meri (ja rannikon läheisen kumpuamisen tapauksessa lisäksi rantaviiva), aiheuttajana tuuli. Kuvan elementteihin on asetettu kirjoitettuna tekstinä nimilappuja (ks. Martinec \& Salway 2005: 355; Unsworth \& Cléirigh 2009), ja nuoli diagrammaattisena elementtinä toimii liikkeen kuvaukseen vakiintuneena semioottisena resurssina. Kuva esittää luonnollisen kohteensa suodatettuna: kaikki ymmärtämisen kannalta ylimääräinen ja epäolennainen aines on karsittu minimiin. Kuva vastaa tekstiin erottamalla ja tekemällä näkyviksi ne kategoriat, joista teksti puhuu. (Lynch 1990: 160-162.)

Kuva esittää tapahtumaa, joka näkyy tuulta kuvaavana nuolena ja toisaalta veden liikettä kuvaavana tummansinisenä kaistaleena; näkyvissä on sosiosemiotiikan termein narratiivinen, transaktionaalinen toimintaprosessi (Kress \& van Leeuwen 1996: 61). Kuvan esittämä representaatio on kongruentti rinnakkaisen kielellisen prosessikuvauksen kanssa, jossa siinäkin kuvataan materiaalinen prosessi (ks. Halliday \& Matthiessen 2014: 224-245). Ensimmäisessä virkkeessä toiminta näyttäytyy transitiivisena: tekijä (tuulen ajovirta) saa toiminnallaan muutoksen aikaan (aiheuttaa) kohteessa (pystysuuntaista virtausta). Myöhemmin materiaalinen prosessi esitetään myös intransitiivisena: tekijä (vesi) vaikuttaa itseensä (kulkeutuu). Yhtä kaikki teksti ja kuva representoivat rinnakkain samanlaiset materiaaliset prosessit. Martinin ja Rosen (2008) genreteoriassa tällaista prosessin suoria ja peräkkäisiä syy-seuraussuhteita selostavaa tekstiä nimitetään vaiheittaiseksi selitykseksi (sequential explanation, mts. 150-157; ks. myös Wignell, Martin \& Eggins 1993: 156-158). 
Toinen kuvan tarttumakohta leipätekstissä on - kuvatekstin kautta - esimerkkikatkelman viimeisessä kappaleessa, joka käsittelee rannikolla tapahtuvaa kumpuamista. Siinä leipätekstiä on siirretty kuvatekstiin vain pienin muutoksin. Kuvalla on siis kaksi tarttumakohtaa: siihen viitataan suoraan heti kumpuamista yleisesti esiteltäessä, mutta kuvatekstin lähteenä oleva leipäteksti tulee vasta myöhemmin, rannikolla tapahtuvaa kumpuamista käsiteltäessä. Jos lukija seuraa ensimmäistä viitettä kuvaan, hän saa leipätekstiä lukiessaan toisteista informaatiota. Kuvalle voikin hahmottaa erilaisia tehtäviä leipätekstin edetessä sen rinnalla. Alussa kuva auttaa hahmottamaan uutta ilmiötä, toisen kerran lukija voi palata kuvaan vankemmin tiedoin, kun huomaa tuttua asiaa. Tästä kuvaan palaamisesta syntyy ns. ympyrä sulkeutuu -efekti (vrt. Heikkilä 2006: 239). Kuvan tarkempi lukeminen kiinnittyy rannikon läheisen kumpuamisen yksityiskohtaisempaan tarkasteluun, siinä missä ensimmäinen tarttumakohta, viittaus kuvan tunnistenumeroon, on tarkoitettu yleislaatuisemmaksi ja pikaisemmaksi vilkaisuksi, joka tukee käsityksen muodostumista kumpuamisilmiöstä ylipäänsä. Heikkilä (2006: 237-251) jaottelee kuvatekstit leipätekstiä täydentäviin, toistaviin ja tiivistäviin. Esimerkissä 1 kuvateksti on enimmäkseen leipätekstiä toistava (mts. 244). Kuitenkin viimeisessä virkkeessä leipätekstin tietoja täydennetään ylimääräisellä yksityiskohdalla: Voimakkain kumpuaminen tapahtuu kapealla vyöhykkeellä - - (vrt. mts. 242).

Kumpuamisen selitysjakso jäsentyy siis tiedonrakennuksen kannalta seuraavasti: kirjoittaja esittelee ensin termin yleisellä tasolla antamalla määritelmän sekä vieruskäsitteen ja esittämällä positiivisen arvion ilmiön merkittävyydestä meren ekosysteemille. Samalla kirjoittaja esittelee termin nimeämisen avulla lukijalle kumpuamisen ilmiönä, ja nimilapun saaminen tukee ilmiön hahmottamista käsitteellisenä kokonaisuutena (ks. Karvonen 1995: 142; Wignell, Martin \& Eggins 1993). Mikrotason strategiana on kuvata lyhyesti luonnossa esiintyvä prosessi (Tuulen ajovirta aiheuttaa - -), tiivistää se käsitteeksi (Nousevaa virtausta pinnalle - -) ja nimetä tämä käsite (kutsutaan kumpuamiseksi). Samalla kirjoittaja viittaa kuvaan metatekstuaalisesti: kuva on ensimmäisen tarttumakohdan kautta osa selitysjakson käynnistävää toimintoa, ESITTELYÄ. Termin nimeävän ja siitä yleiskuvan antavan ESITTELYN jälkeen kirjoittaja kertoo kumpuamisen esiintymispaikoista - avomerestä ja rannikosta - ja kuvaa ilmiön ominaisuuksia tarkemmin näissä kummassakin. Tätä ilmiötä tarkemmin elaboroivaa toimintoa nimitän yksinkertaisesti KUVAUKSEKSI. Elaborointi näkyy teemankulussa jakautuvana reemana (Shore 2008: 41): esimerkin toisen kappaleen aloittavan lauseen reema (voi esiintyä sekä avomerellä että rannikolla) poikii tulevien kappaleiden teemat, avomerellä ja rannikolla esiintyvän kumpuamisen. Rannikon läheisen kumpuamisen kuvaus luo toisen tarttumakohdan kuvaan toisteisen kuvatekstin kautta.

Koska kuva on kaavamainen yksinkertaistus luonnosta ja kuvaa todellisuutta valikoiden esitettäviksi ainoastaan selitettävän ilmiön kannalta olennaiset elementit, toteutuu kuvassa tieteellis-teknologinen koodausorientaatio (Kress \& van Leeuwen 
1996: 170). Yhdessä vaiheittaisen selittämisen genreen (Martin \& Rose 2008: 150157) lukeutuvan, yleisesti pätevää eli geneeristä prosessia kuvaavan tekstin kanssa se muodostaa tasapainoisen ekspositiosuhteen (exposition, Martinec \& Salway 2005: 356), jossa kuva ja teksti esittävät yhtä geneeristä tietoa. Ekspositiosuhteen myötä selitysjaksossa toteutuva toimintokuvio, ESITTELY-KUVAUs, toteutuu tekstin ja kuvan yhteispelinä. Kuvalla on kaksi tarttumakohtaa leipätekstissä ja siten kaksi erilaista tehtävää selitysjakson kulussa: kumpuamisilmiön yleinen havainnollistus ja tarkempi rannikon läheisen kumpuamisen esittely.

\subsection{Kuva ESIMERKKINÄ}

Esimerkki 2 on suomalaista kansanuskoa käsittelevän kirjan luvusta, jossa esitellään erilaisia luonnon henkiolentoja. Uskomusolentojen nimitykset ovat siinä mielessä laadultaan erityisiä, että niiden tarkoitteet ovat olemassa yhteisöllisissä uskomuksissa ja kulttuuriperinteessä. Olennot ovat eläneet suusta suuhun kiertäneissä kertomuksissa ja uskomuksissa, joihin tutkijat voivat erilaisten arkisto- ja muiden tietolähteiden avulla päästä käsiksi ja esittää käsityksensä siitä, millaisina uskomusolennot on aikanaan kulttuurisessa kontekstissaan nähty. Kansanuskomuksia tieteellisesti tutkittaessa erilaisissa kertomuksissa eläneet olennot asetetaan uskontotieteelliseen luokitteluun, ja niiden nimityksiä käytetään teoksen tekstissä tieteenalan termeinä. Useilla tieteenaloilla onkin tavallista, että käsitejärjestelmä muotoutuu osittain yhteneväiseksi yleiskielisen kansantaksonomian kanssa. Käsitteet kuitenkin määritellään, nimetään termeillä ja järjestetään taksonomioiksi tieteenalan omien lähtökohtien ja luokitteluperusteiden mukaisesti (Wignell, Martin \& Eggins 1993: 137-143).

Kirjoittaja käyttää esimerkissä 2 selittämisen toimintokuviota ESITTELY-ESIMERKKI. Siinä metsänhaltija tehdään ensin tutuksi erilaisia uskomusperinteitä yhdistävänä käsitteenä sekä esitellään sen kontekstia kansanuskon tutkimuksen kentässä. Sitten yleisestä tiedosta siirrytään konkreettiseen välittämällä kokemuksellista ja partikulaarista tietoa kuvan ja lyhyiden aikalaiskertomusten muodossa. Tekstikatkelmat edeltävät kokonaisuudessaan kuvaa, joka näkyy vasta leipätekstin siirtyessä jo veden henkiolentoihin.

(2) Metsän ja veden jumaluudet

[--]

Sekä Länsi- että Itä-Suomessa tunnettiin myös paikallisia metsänhaltijoita. Erämiehet näyttävät uhranneen myös näille saaliin toivossa. Arkistomuistiinpanojen perusteella on tosin usein vaikea päätellä, onko uhrin saaja kaikkiallinen jumaluus vai paikallinen haltija. Paikallisia metsänhaltijoita yleensä myös pelättiin. Tämä piirre on sopusoinnussa Siperian suomensukuisilla kansoilla tavattavien uskomusten kanssa. Näiden mukaan paikallinen metsän- tai vedenhaltija tulee kyseiseen metsään menehtyneestä tai paikalliseen vesistöön hukkuneesta ihmisestä. Metsänhaltijan intresseissä on tällöin eksyttää inmisiä. - - Uskomus on havaittu monin paikoin myös Suomesta, joskin metsänhaltija harvemmin aiheutti suoraan 
inmisen kuoleman. Metsänhaltijan jäljille joutumisesta seurasi kuitenkin helposti niin sanottu metsänpeitto. - - (Pulkkinen 2014: 73.)

Läntisessä Suomessa paikallisia metsänhaltijoita koskevaan perinteeseen on vahvasti vaikuttanut skandinaavinen skogsjungfru-traditio. Nämä naispuoliset haltijat olivat luonteeltaan eroottisia. - - Perinne on hyvin kerrostunutta ja vaihtelee alueittain, ja eri olentoja koskevat traditiot ovat usein sekoittuneet keskenään. - (Pulkkinen 2014: 75.)

Metsän pelottavuutta eli sen tremendum-luonnetta ovat puolestaan edustaneet pelottavat paikalliset, etenkin naispuoliset metsänhaltijat. (Pulkkinen 2014: 76.)

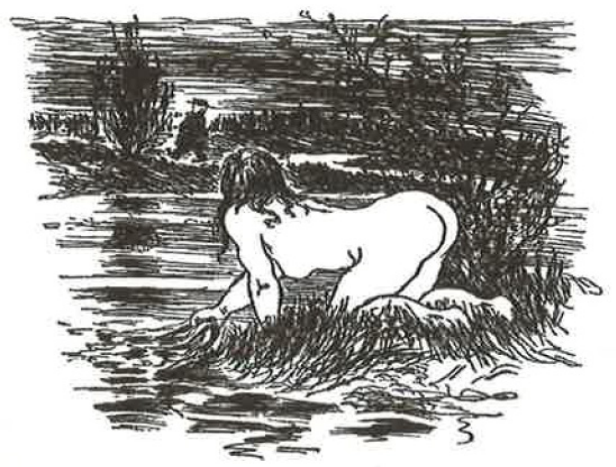

MetsänhaltuJa menossa keikis telemään metsämiesten tulille.

(Pulkkinen 2014: 77.)

Lisäksi kirjoittaja esittää esimerkkitapauksina neljä toisen äänen kertomusta ihmisten kohtaamisista metsänhaltijan kanssa, esimerkiksi seuraavan:

Ilkka-niminen metsästäjä oli kerran mettäs pitänyt nuotion ja siihen nuotion toisellep puolelle tuli alaston nainen keimailemaan. Niin llikka ampun sitä, ja se juoksi mettään. (Pulkkinen 2014: 75.)

Kirjoittaja siis käyttää metsänhaltija-olennon esittelyyn monipuolisia tiedonrakennuksen keinoja: geneeristä kuvausta ja määrittelyä, kuvaa ja kertomuksia. Metsänhaltijoita kuvataan menneessä aikamuodossa ihmisten kokemuksen kautta (tunnettiin, pelättiin). Tietoa rakentavana resurssina kuva muistuttaa tunnistuskuvaa (Koponen ym. 2017: 129): edustavaa kuvaa esiteltävän lajin yksilöstä. Toisaalta tapahtumakuvauksena se esittää edustavaa ja yleistettävää erityistapausta. Havainnollistavan esimerkkiyksilön kuvaaminen ja siihen liittyvä - enemmän tai vähemmän implisiittinen - edustavuuden vaatimus tekee näkyväksi kirjoittajan käsityksen kategorian prototyyppisestä edustajasta. Tässä tapauksessa kuvatuksi on valittu nimenomaan skandinaavisen tradition mukaisesti feminiininen ja eroottinen (keikistelemään) hahmo. Tietokuvituksessa tunnistettavuus nojaa usein kulttuurisiin stereotyyppeihin, mikä voi olla myös ongelmallista (ks. mts. 135-137). 
Kuvan asettelu rakentaa käsitystä olennon luonteesta: se väijyy pahaa-aavistamatonta metsämiestä (vrt. Kress \& van Leeuwen 1996: 44). Kuva representoi narratiivisen prosessin, jossa metsänhaltija on rooliltaan tekijä ja metsämies kohde - metsänhaltijan katse, joka tosin on lukijan näkymättömissä mutta oletettavissa, muodostaa vektorin, joka kohdistuu metsämieheen (mts. 63). Kuvateksti ilmaisee metsänhaltija-subjektin intransitiivista toimintaa, jossa kohteena olevat metsämiehet kuitenkin käyvät epäsuorasti ilmi; toiminta on verbin infinitiivimuodon avulla (menossa) pysäytetty still-kuvan tavoin tiettyyn hetkeen. Metsänhaltija on etualaistettu ja asetettu kuvan keskiöön. Silmiinpistävimpänä elementtinä se on kuvan teema. Lukija asettuu tapahtuman sivustakatsojaksi: häneen ei suoraan oteta kontaktia katseella, vaan kirjoittaja tarjoaa tapahtuman lukijan katseltavaksi. Kuva on rajattu siten, että kaksi hahmoa ja niiden välinen suhde muodostavat kuvan viestin. (Ks. Kress \& van Leeuwen 1996; O'Toole 1994: 6-12, 157.)

Kuva on taiteilijan näkemys, jonka koodausorientaatio on samaan aikaan sekä naturalistinen että aistillinen (Kress \& van Leeuwen 1996: 170): se esittää tapahtuman, joka olisi sellaisenaan nähtävissä paikan päällä, toisaalta sen mustavalkoisuus ja piirroksisuus korostavat aistillista elämystä. Teksti puolestaan esittelee ja erittelee historiallisia käsityksiä, ja se voidaan nähdä tieteellisen kuvauksen (descriptive report, Martin \& Rose 2008: 142-144) genren edustajana; olennaista on, että se esittää tietoa yleisesti pätevänä. Teksti on geneerisempi kuin tiettyä, yksittäistä tapahtumaa esittävä kuva, minkä seurauksena kuva on konkretisoiva esimerkki suhteessa tekstiin (Martinec \& Salway 2005: 356). ${ }^{3}$

Kuvateksti sanoittaa kuvan spesifin tilanteen. Tämä näkyy myös verbien kieliopillisessa muodossa: paikallissijainen infinitiivi selostaa juuri kyseisen kuvan tapahtumaa, siinä missä leipätekstissä aikalaiskokemuksiin viitataan menneessä muodossa: tunnettiin, pelättiin (vrt. Heikkilä 2006: 138-140). Kuvalla ja sen asettelulla tuodaan henkiolennon kulttuurista kontekstia lähemmäs lukijan kokemusmaailmaa ja tehdään sen roolia aikansa kansanuskossa ymmärrettäväksi: haltijoiden uskottiin väijyvän luonnossa kulkijoita, minkä tähden tuli olla varuillaan. Näin geneerinen käsitteellinen tietämys, joka näkyy tekstissä metsänhaltijaperinteen kielennyksissä (pelättiin, naispuoliset, luonteeltaan eroottisia, pelottavuutta, tremendum-luonnetta), täydentyy kuvalla, jossa nämä ominaisuudet aineellistuvat spesifin tilannekuvan visuaalisina piirteinä (perspektiivi, värikontrasti, alastoman naisen hahmo). Tekstissä esitetyt käsitepiirteet - tässä luonto, naiseus ja pelättävyys - ovat siis näkyvissä myös kuvassa (vrt. kumpuamisen käsitepiirteisiin yllä). keskityn tässä käytännön syistä sen esittämään informaatioon. Kulttuurisen kontekstin näkökulmasta kuva on kiinnostavalla tavalla rekontekstualisoitu: se on peräisin Lauri Simonsuuren kirjasta Myytillisiä tarinoita vuodelta 1947. Kyseessä on antropologinen kokoelma kansantarinoita, jossa on Erkki Tuomen kuvitus; huomattavaa on, että tuossa teoksessa kuva esiintyy ilman kuvatekstiä. 
Kirjoittaja siis esittelee termin metsänhaltija ensin yleisellä käsitteellisellä tasolla ja valaisee sen kontekstia, jonka jälkeen hän siirtyy täydentämään geneeristä tietoa tapausesimerkeillä, spesifiä tilannetta esittävillä kertomuksilla ja kuvalla. Vuorovaikutus jäsentyy toimintokuvioksi ESITTELY-ESIMERKKI, jossa kuva toimii ESIMERKKI-toimintona. Kuva kiinnittyy leipätekstissä niihin kohtiin, joista on tunnistettavissa eroottinen, pelottava ja metsämiehiä viettelevä metsänhaltija. Niin kirjoitetut tapauskertomukset kuin kuvakin ovat esimerkkisuhteessa geneeriseen, käsiteavaruutta esittelevään tekstiin. Kertomukset voidaan ajatella esimerkin 1 tapaan rinnakkaisina ESIMERKKI-toiminnon toteuttajina tai niiden voidaan nähdä asettuvan toimintokuvioon ESITTELY-ESIMERKKI erikseen. Jälkimmäistä tulkintaa perustelee se, että kuva (ja kuvateksti) ei selkeästi kiinnity tiettyyn kertomukseen, vaan pikemminkin kertomukset ja kuva ovat kaikki erillisiä (rinnakkaisia ja multilineaarisia) ESIMERKKEJÄ ESITTELY-toiminnolle.

Kirjoittaja välittää lukijalle samalla tietoa henkiolentoja luokittelevan käsitejärjestelmän luonteesta sekä uskontotieteen ja perinteentutkimuksen tieteenaloista (Perinne on hyvin kerrostunutta - -). Uskomusperinne ja kertomukset vaihtelevat, ja samankaltaisista ja samannimisistä olennoista on ollut olemassa useita eri traditioita, joita on tutkimuksessa yhdistelty ja abstrahoitu tiettyjen termien alle. Näin lukija saa paitsi yleisen ja abstraktin käsityksen termistä, sen rajoista ja käytöstä myös konkreettista tietoa siitä, millaisena metsänhaltija on koettu ihmisten keskuudessa - ja lisäksi siitä, miten näitä asioita tutkitaan. Kirjoittajan strategia on yhdistellä laadultaan erilaista informaatiota termistä ja sen nimeämästä ilmiöstä ja näin rakentaa monipuolista tietoa lukijalle (vrt. Lemke 1990: 113; Calsamiglia \& van Dijk 2004).

\section{$5 \quad$ Lopuksi}

Olen tässä artikkelissa tutkinut kahden esimerkin avulla, millaisissa tehtävissä kuvallisia resursseja voidaan käyttää osana termien selittämistä ja termin takana olevan käsitteen kuvaamista tietokirjoissa. Samalla olen esitellyt multimodaalisen toimintokuvion välineenä, jonka avulla kuvaa ja sanaa yhdistävää tekstikokonaisuutta voidaan jäsentää kirjoitetun vuorovaikutuksen näkökulmasta. Niin kirjoitetun tekstin kuin kuvan esitystapaa ohjaa sen tehtävä osana tietoa rakentavaa vuorovaikutusta. Esimerkiksi erilaisten prosessien kielellinen kuvaus ja prosesseja esittävät tieteellis-teknologisesti orientoituneet kuvat ovat keskenään ekspositiosuhteessa ja toteuttavat siten rinnakkain samoja toimintoja. Naturalistis-aistillisesti orientoitunut kuva puolestaan on esimerkkisuhteessa kansanperinteen käsiteavaruutta geneerisesti esittelevään tekstiin. Tarkasteltaessa kuvia kirjoitettuna vuorovaikutuksena kontekstissaan niiden sisäiset piirteet hahmottuvat tavoitteellisiksi valinnoiksi osana tekstilajia ja sen kommunikatiivisia tavoitteita. 
Tiedon esittämiseen käytettäviä semioottisia resursseja ohjaavat osaltaan tieteenalan kulttuuriset käytänteet. Luonnontieteellisten prosessien kuvaukseen ovat vakiintuneet erilaiset kaavakuvat ja diagrammit, kun taas muinais- ja kansanuskoa esittelevät tekstit nojaavat usein piirrettyyn tai maalattuun kuvitukseen. Kuvien yleisemmäksi tehtäväksi hahmottuu Hylandin (2010: 119) ajatuksen mukaisesti nimenomaan kyseenalaistamattoman, "valmiin" tiedon havainnollistaminen, siinä missä tieteellisissä teksteissä kuvilla tyypillisesti esitetään todisteita päätelmille ja tuetaan argumentointia. Termien merkitys ja käyttötavat esitetään esimerkeissä valmiina ja ongelmattomina lähtökohtina, eikä luokittelu- ja valintaperusteita ole kirjoitettu näkyviin (ks. Karvonen 1995: 144; Wignell 1998: 323). Tiedettä yleistajuistava teksti nojaa intertekstuaalisesti tieteellisiin teksteihin ja tieteelliseen keskusteluun, jossa neuvottelua tieteenalan keskeisistä tutkimuskohteista ja luokitteluperusteista on jo käyty - tätä kulttuurista taustaa vasten termit voidaan sellaisinaan ottaa lähtökohdiksi niitä erikseen perustelematta (ks. Karvonen 1995: 207).

Erilaisia tieteenaloja edustavissa esimerkeissä 1 ja 2 näkyy termien tarkoitteiden ero, joka pohjautuu erilaisiin tutkimuskohteisiin ja episteemisiin lähtökohtiin. Luonnontieteen käsitteenmuodostuksessa tyypillisesti jokin luonnossa havaittava olio tai ilmiö nimetään termillä ja luokitellaan osaksi käsitejärjestelmää. Kyseessä on siis nimilapun kytkeminen maailmassa havaittaviin kokonaisuuksiin, jotka termiksi nimeämisen kautta saavat identiteetin osana tieteenalan tietoa ja rajatun merkityksen tieteenalan diskurssiyhteisössä (käsitteestä ks. Swales 1990). Ihmistieteille puolestaan on ominaista, että tarkoitteita luodaan käsitteillä, abstrahoimalla yksittäisistä tapahtumista kategorioita. Tieteenalan edustajien muodostaman diskurssiyhteisön kielenkäytössä nämä kategoriat vakiintuvat ja teknistyvät edelleen tieteellisiksi termeiksi. (Wignell 1998.) Tämä ero näkyy myös yleistajuisissa teksteissä: kumpuaminen on luonnosta osoitettava ilmiö, jolle termin selitysjakso antaa nimen. Metsänhaltija-termin abstrahointiprosessi yksittäisistä paikallisista kertomustraditioista taas näkyy erilaisina maantieteellisesti varioivina piirteinä ja kerrostuneena perinteenä: termin merkityksen ymmärtämiseen kuuluu elimellisenä tämän moninaisuuden ja kerroksellisuuden hahmottaminen.

Selittäviä multimodaalisia toimintokuvioita tulisi jatkossa tutkia laajentamalla sekä aineistoa että menetelmiä. Toimintokuvioita voisi tarkastella esimerkiksi kaksiulotteisen sivutilan rakenteen kattavalla analyysilla (esim. Bateman 2008; Hiippala 2013) sekä silmänliiketutkimuksen metodein (esim. Holsanova 2014; Bateman, Wildfeuer \& Hiippala 2017: 159-162). Lisäksi erilaiset korpusmenetelmät - esimerkiksi kuvien koodaaminen tekstianalyysiohjelmalla kuvien lajin ja niiden toteuttamien toimintojen mukaan - saattaisivat valottaa multimodaaliseen tekstikokonaisuuteen kirjoitetun vuorovaikutuksen anatomiaa. Selvää kuitenkin on, että tarvetta jatkotutkimukselle on vastakin suomenkielisen tietokirjallisuuden ja yleistajuisen tieteen esitystavoissa ja niiden analyysin sovelluksissa. 


\section{Aineistolähteet}

Myrberg, K. \& M. Leppäranta 2014. Meret. Maapallon siniset kasvot. Helsinki: Ursa.

Pulkkinen, R. 2014. Suomalainen kansanusko. Samaaneista saunatonttuihin. Helsinki: Gaudeamus.

\section{Kirjallisuus}

Bateman, J. 2008. Multimodality and Genre: A Foundation for the Systematic Analysis of Multimodal Documents. London: Palgrave Macmillan.

Bateman, J., J. Wildfeuer \& T. Hiippala 2017. Multimodality. Foundations, research and analysis. A problem-oriented introduction. Berlin: De Gruyter Mouton.

Butcher, K. 2014. The multimedia principle. Teoksessa R. Mayer (toim.) The Cambridge handbook of multimedia learning. New York: Cambridge University Press, 174-205.

Calsamiglia, H. \& T. van Dijk 2004. Popularization discourse and knowledge about the genome. Discourse \& Society 15 (4), 369-389. https://doi. org/10.1177/0957926504043705.

Coopmans, C., J. Vertesi, M. Lynch \& S. Woolgar 2014. Representation in scientific practice revisited. Cambridge, Massachusetts: The MIT Press.

Dancygier, B. \& L. Vandelanotte 2017. Internet memes as multimodal constructions. Cognitive Linguistics 28 (3). https://doi.org/10.1515/cog-2017-0074.

Dalton-Puffer, C. 2007. Discourse in content and language integrated learning (CLIL) classrooms. Amsterdam/Philadelphia: John Benjamins.

Forceville, C. 2007. Book review: Multimodal Transcription and Text Analysis: A Multimedia Toolkit and Coursebook. Journal of Pragmatics 39 (6), 1235-1238. https://doi. org/10.1016/j.pragma.2007.02.007.

Halliday, M. A. K. \& C. Matthiessen 2014. Halliday's introduction to functional grammar. London: Routledge.

Heikkilä, E. 2006. Kuvan ja tekstin välissä. Kuvateksti uutiskuvan ja lehtijutun elementtinä. Helsinki: Suomalaisen Kirjallisuuden Seura.

Hiidenmaa, P. 2018. Tekijä ja lukija tietokirjan kynnysteksteissä. Teoksessa T. Rahtu, S. Shore \& M. Virtanen (toim.) Kirjoitettu vuorovaikutus. Helsinki: Suomalaisen Kirjallisuuden Seura, 80-115.

Hiidenmaa, P., M. Virtanen, H. Satokangas, E. Vitikka \& I. Lindh 2018. Tiedonkerronta. Esitystavat ja tekijän läsnäolo kotimaisessa tietokirjallisuudessa. Avain 4/2018, 82-86. https://doi.org/10.30665/av.76583.

Hiippala, T. 2013. Modelling the structure of a multimodal artefact. Helsinki: University of Helsinki.

Hoey, M. 1983. On the surface of discourse. London: George, Allen \& Unwin.

Hoey, M. 2001. Textual interaction. An introduction to written discourse analysis. London: Routledge.

Holsanova, J. 2014. Reception of multimodality: applying eye tracking methodology in multimodal research. Teoksessa C. Jewitt (toim.) The Routledge Handbook of multimodal analysis. Toinen painos. London: Routledge, 287-298.

Hovmark, H. (2010). Gid man kunne have bragt en tegning! Om definitioner og illustrationer i ensproglige ordbøger. Skrifter udgivet af Nordisk Forening for Leksikografi 11, 192-208. https://tidsskrift.dk/nsil/article/view/19231. 
Hyland, K. 2010. Constructing proximity: Relating to readers in popular and professional science. Journal of English for Academic Purposes 9, 116-127. https://doi.org/10.1016/j. jeap.2010.02.003.

Jewitt, C. 2009. Different approaches to multimodality. Teoksessa C. Jewitt (toim.) The Routledge handbook of multimodal analysis. London: Routledge, 28-39.

Järvinen, S. 2001. Sanojen selittämisestä suomi toisena kielenä -oppitunneilla. Teoksessa T. Nieminen (toim.) Vuorovaikutus ja suomen kielen oppiminen. Kakkoskieli 3. Helsinki: Helsingin yliopiston suomen kielen laitos, 173-258.

Karvonen, P. 1995. Oppikirjateksti toimintana. Helsinki: Suomalaisen Kirjallisuuden Seura.

Ketola, A. 2018. Word-image interaction in technical translation. Students translating an illustrated text. Tampere: Tampere University Press.

Koivisto, J. 2011. EU-artiklar som multimodala budskap. Text, bild och begriplighet $i$ rapporteringen om EU-utvidgningen i finska och svenska morgontidningar år 2002 och 2004. Tampere: Tampere University Press 2011.

Komppa, J. 2012. Retorisen rakenteen teoria. Teoksessa V. Heikkinen, E. Voutilainen, P. Lauerma, U. Tiililä \& M. Lounela (toim.) Genreanalyysi - Tekstilajitutkimuksen käsikirja. Helsinki: Gaudeamus, 186-193.

Koponen, J., J. Hildén \& T. Vapaasalo 2017. Tieto näkyväksi. Informaatiomuotoilun perusteet. Helsinki: Aalto-yliopisto.

Kress, G. \& T. van Leeuwen 1996. Reading images. The grammar of visual design. London: Routledge. [Uusittu painos 2006.]

Lemke, J. 1990. Talking Science. Language, learning, and values. New York: Ablex.

Lemke, J. 1998. Multiplying Meaning. Visual and Verbal Semiotics in Scientific Text Teoksessa J. Martin \& R. Veel (toim.) Reading Science. London: Routledge, 87-113.

Luzón, M. 2009. Scholarly hyperwriting: The function of links in academic weblogs. Journal of the American Society for Information Science and Technology 60 (1), 75-89. https:// doi.org/10.1002/asi.20937.

Luzón, M. 2013. Public communication of science in blogs: Recontextualizing scientific discourse for a diversified audience. Written Communication 30 (4), 428-457. https:// doi.org/10.1177/0741088313493610.

Lynch, M. 1990. The Externalized Retina. Selection and Mathematization in the Visual Documentation of Objects in the Life Sciences. Teoksessa M. Lynch \& S. Woolgar (toim.) Representation in scientific practice. Cambridge, Massachusetts: MIT Press.

Löytönen, M. 2017. Miten kirjojen kuvamaailma on muuttunut? Teoksessa P. Hiidenmaa (toim.) T niin kuin tietokirjallisuus. Helsinki: Äidinkielen opettajan liitto, 101-108.

Machin, D. \& A. Jaworski 2006. Archive video footage in news: creating a likeness and index of the phenomenal world. Visual Communication 5, 345-366. https://doi. org/10.1177/1470357206068464.

Makkonen-Craig, H. 2014. The emergence of a research tradition: Dialogically-oriented linguistic discourse analysis. Teoksessa A.-M. Karlsson \& H. Makkonen-Craig (toim.) Analysing text AND talk. Att analysera texter OCH samtal. Uppsala: Institutionen för nordiska språk, Uppsala universitet, 121-132. http://uu.diva-portal.org/smash/get/ diva2:757298/FULLTEXT02.pdf.

Mann, W. \& S. Thompson 1988. Rhetorical structure theory: toward a functional theory of text organization. Text, 8 (3), 243-281. https://doi.org/10.1515/text.1.1988.8.3.243.

Marsh, E. \& M. White 2003. A taxonomy of relationships between images and text. Journal of Documentation, 59 (6), 647-672. https://doi.org/10.1108/00220410310506303.

Martin, J. \& D. Rose 2008. Genre Relations. Mapping Culture. London: Equinox.

Martinec, R. \& A. Salway 2005. A system for image-text relations in new (and old) media. Visual Communication 4 (3), 337-371. https://doi.org/10.1177/1470357205055928. 
Merke, S. 2016. Establishing the explainable in Finnish-as-a-foreign-language classroom interaction: Student-initiated explanation sequences. Learning, Culture and Social Interaction 9, 1-15. https://doi.org/10.1016/j.Icsi.2016.03.002.

Mikkonen, K. 2005. Kuva ja sana. Kuvan ja sanan vuorovaikutus kirjallisuudessa, kuvataiteessa ja ikonoteksteissä. Helsinki: Gaudeamus.

Morton, T. 2015. Vocabulary explanations in CLIL classrooms: a conversation analysis perspective. The Language Learning Journal, 43, 256-270. https://doi.org/10.1080/095 71736.2015.1053283.

Mäntynen, A. 2003. Miten kielestä kerrotaan. Kielijuttujen retoriikkaa. Helsinki: Suomalaisen Kirjallisuuden Seura.

Nikolajeva, M. \& C. Scott 2006. How Picturebooks Work. New York: Routledge.

Nord, A. 2008. Trädgårdsboken som text 1643-2005. Stockholm: Acta Universitatis Stockholmiensis.

Oittinen, R., A. Ketola \& M. Garavini (toim.) 2017. Translating picturebooks. Revoicing the verbal, the visual and the aural for a child audience. New York: Routledge.

O'Toole, M. 1994. The language of displayed art. Leicester University Press.

Pasanen, P. 2015. Tavallisten kielenkäyttäjien käsityksiä termeistä. Teoksessa D. Rellstab \& N. Siponkoski (toim.) Rajojen dynamiikkaa, Gränsernas dynamik, Borders under negotiation, Grenzen und ihre Dynamik. VAKKI-symposiumi XXXV 12.-13.2.2015. Vaasa: VAKKI Publications, 178-187. http://www.vakki.net/publications/2015/VAKKI2015_ Pasanen.pdf.

Pälli, P. 2003. Ihmisryhmä diskurssissa ja diskurssina. Tampere: Tampere University Press.

Raevaara, T. 2016. Tajuaako kukaan? Opas tieteen yleistajuistajalle. Tampere: Vastapaino.

Rahtu, T. 2013. Tieteellisestä yleistajuiseen kielenkäyttöön. Teoksessa U. Strellman \& J. Vaattovaara (toim.) Tieteen yleistajuistaminen. Helsinki: Gaudeamus, 99-118.

Rahtu, T., S. Shore \& M. Virtanen (toim.) 2018. Kirjoitettu vuorovaikutus. Helsinki: Suomalaisen Kirjallisuuden Seura.

Rose, D. \& J. Martin 2012. Learning to write, reading to learn. Genre, knowledge and pedagogy in the Sydney school. London: Equinox.

Satokangas, H. (tulossa). Termien havainnollistamisen kerronnalliset keinot yleistajuisissa tietokirjoissa. Näkökulmana toimintokuviot. Hyväksytty julkaistavaksi.

Satokangas, H. (tekeillä). Termien selittämisen toimintokuviot yleistajuisessa tietokirjassa. Käsikirjoitus.

Shore, S. 2008: Lauseiden tekstuaalisesta jäsennyksestä. Virittäjä 112, 24-65. https://journal. fi/virittaja/article/view/40639.

Shore, S. 2014. Reading to learn -genrepedagogiikan kielitieteellinen perusta. Teoksessa S. Shore \& K. Rapatti (toim.) Tekstilajitaidot. Lukemisen ja kirjoittamisen opetus koulussa. Helsinki: Äidinkielen opettajain liitto, 37-63.

Swales, J. 1990. Genre analysis. English in academic and research settings. Cambridge: Cambridge University Press.

Thompson, G. 2001. Interaction in academic writing. Learning to argue with the reader. Applied Linguistics 22/1, 58-78. https://doi.org/10.1093/applin/22.1.58.

Thompson, G. 2012. Intersubjectivity in newspaper editorials. Construing the reader-inthe-text. English Text Construction 5 (1), 77-100. https://doi.org/10.1075/bct.65.05tho.

Thompson, G. \& S. Hunston 2000. Evaluation: an introduction. Teoksessa S. Hunston \& G. Thompson (toim.) Evaluation in text. Authorial stance and the construction of discourse. Oxford: Oxford University Press, 1-27.

Thompson, G. \& P. Thetela 1995. The sound of one hand clapping. The management of interaction in written discourse. Text 1, 103-127. https://doi.org/10.1515/ text.1.1995.15.1.103. 
TSK 1988 = Sanastotyön käsikirja. Soveltavan terminologian periaatteet ja työmenetelmät. Toim. Tekniikan Sanastokeskus ry. TSK 14. Helsinki: Suomen Standardisoimisliitto SFS ja Tekniikan Sanastokeskus ry.

Unsworth, L. \& C. Cleirigh 2009. Multimodality and reading. The construction of meaning through image-text interaction. Teoksessa C. Jewitt (toim.) The Routledge Handbook of Multimodal Analysis. London: Routledge, 151-163.

Virtanen, M. 2015. Akateeminen kirja-arvio moniäänisenä toimintana. Helsinki: Helsingin yliopiston suomen kielen, suomalais-ugrilaisten ja pohjoismaisten kielten ja kirjallisuuksien laitos.

Virtanen, M. \& L. Kääntä 2018. At the intersection of text and conversation analysis: analysing asynchronous online written interaction. Teoksessa L. Haapanen, L. Lehti \& L. Kääntä (toim.) Diskurssintutkimuksen menetelmistä. On the methods in discourse studies. AFinLA-e. Soveltavan kielitieteen tutkimuksia 2018/11, 137-155. https://doi. org/10.30660/afinla.69081.

Vitikka, E. 2018. Hyperlinkkien funktiot ja kirjoittaja- ja lukijapositiot. Virittäjä 122, 161-186. https://doi.org/10.23982/vir.63134.

Wignell, P. 1998. Technicality and abstraction in social science. Teoksessa J. Martin \& R. Veel (toim.) Reading science. Critical and functional perspectives on discourses of science. London: Routledge, 297-326.

Wignell, P., J. Martin \& S. Eggins 1993. The discourse of geography: Ordering and explaining the experiental world. Teoksessa M. Halliday \& J. Martin (toim.) Writing science. Literacy and discursive power. London: Falmer Press, 136-165. 